\title{
Duties and Responsibilities of Notary on The Act on His Own Viewed From Act No. 2 of 2014 on The Department of Notary
}

\author{
Elang Yogi Medikabrata ${ }^{1}$, Kurniawan Daeli ${ }^{2}$ and Amin Purnawan ${ }^{3}$
}

Abstract. Notary is a public official who has the authority to make authentic documents and any other authority as referred to in Article 1 paragraph (1) of Act no. 2 of 2014 on the amendment of Act No. 30 of 2004 on the department of notary. The aim of this study was to: 1) To determine the duties and responsibilities of the Deed made by it in carrying out its duties and his position based on Act no. 2 of 2014 concerning Notary. 2) To find out the weaknesses of the duties and responsibilities of the Deed made by Act no. 2 of 2014 concerning Notary. 3) To find a solution weakness of the duties and responsibilities Against the Act made. The data used in this study are primary data, secondary and tertiary then analyzed by juridical empirical method that is reviewing the law relating to the issues discussed.

Based on the data analysis concluded that: 1) The duties and responsibilities of a notary deed prepared to very low and many things that are broken. 2) the provisions set forth in Act no. 2 of 2014 concerning Notary less able to protect the client. 3) the provisions set forth in Act no. 2 of 2014 concerning on Department of Notary must include also the protection of the client as a result of the negligence of the notary who is aggrieved clients.

Keywords: Notary Duties; Responsibilities Notary; Deed Of Notary.

\section{Introduction}

Notary law (UUJN) have jointly Using the institution of the Department (Notary) and notary as a profession (notary profession) or equivalent terms (equivalent to) use. As mentioned in the Preamble Considering c, namely that of a department that runs the profession in the service of the law to the public, and in Article 1 paragraph 5 of the aforementioned organization Notary is a professional organization of Notary shaped, when Act no. 30 of 2004 called Notary Law, not the Law on Notarial profession or profession Notary. In this case there have been inconsistencies in citations as a notary and notary Department as a profession. It should simply referred to as the notary department.

Understanding different departments and profession. The presence of a notary institution Beleidsregel of Country by Act no. 30 of 2004 concerning Notary (UUJN) or deliberately created the Department of State as the implementation of the State in providing services to citizens, particularly in the manufacture of authentic evidence recognized by the State. Profession born as a result of the interaction among fellow members of the community, which was born and developed and created by the people themselves.

\footnotetext{
${ }^{1}$ Students of Master of Notary Law Faculty of Law Universitas Islam Sultan Agung Semarang email: elangyogimedikabrata@gmail.com

2 Students of Master of Law, Faculty of Law, Universitas Islam Sultan Agung email kdaely@gmail.com

${ }^{3}$ Lecturer in Faculty of Law Universitas Islam Sultan Agung Semarang
} 
That department and profession are two different things in terms of substance, it will be related to the pattern of this present in many countries. According Zenic notary form or pattern can be divided into two (2) main groups, namely: Notary Functionnel, in which the authority of the government-delegated authority (gedelegeerd), and thus is suspected to have truth in them, have the power of formal proof and has a power / strength of execution. In countries that embrace a wide / notarial form like this there is a hard separation between "wettelijke" and "niet wettelijke" werkzaamheden, which works based on law / law and are not / not in the notary. Notary Professionel, in this group, although the government regulates the organization, but it acts notaries do not have specific consequences of truth, strength of evidence, as well as executory powers. $^{4}$

Article 15 (1) UUJN confirmed that one of the authorities of that is making the act in general, with all the limitations:

- Not excluded the other official applied by law.

- Concerning the certificates must be made or authorized to make authentic act of all acts, agreements, and resolutions required by law or required by the rules in question.

- Regarding the legal subject (person or entity) for the benefit of whom it was made or required to act.

- Authorities regarding the place where the act was done, this is in accordance with a position and area of Notary.

- About the time of the making of, in this case the notary must ensure legal certainty over time the applicant listed in the act.

Act made before a notary or by standing as an authentic act according to the form and manner prescribed in the UUJN, this is in accordance with the opinion of Philip M. Hadjon, that the conditions of authentic documents, namely:

- In the form prescribed by law (the standard form);

- Created by and in front of the General Headquarters.

Submitted by Irawan Soerodjo, that there are three (3) elements in order to satisfy the formal requirements an authentic act, namely:

- In the form prescribed by law;

- Created by and in front of the General Headquarters;

- Act made by or in the presence of the General Office of the authorities to it and the place where the deed was done.

Article 1868 BW is a source for the authenticity of the act is also the basis of the legality of the existence of the act, with the conditions as follows:

- The Act must be made by the (door) or presence (ten Overste) a General Office.

- The Act must be made in the form prescribed by law.

- Public officials by deed or by whom it was made, shall have the authority to make the act. $^{5}$

\footnotetext{
${ }^{4}$ Habib Adjie 2017 Sanksi Perdata dan Administratif Terhadap Notaris Sebagai Pejabat Publik Refika Aditama Bandung (Summized to Habib Adjie I) p. 7-8.

${ }^{5}$ Ibid p 56-57.
} 
It should also be understood that a professional does not mean it should be done by a professional. Notary Department, shall act professional (professional in mind and action) in carrying out his duties, in accordance with the standards set out in UUJN department, which provides the best possible service to the public. ${ }^{6}$

Based on the background mentioned above, the authors are interested in doing further research to be formulated in the form of a study entitled: "Duties And Responsibilities Of Notary On The Act On His Own Viewed From Act No. 2 Of 2014 On The Department Of Notary".

\section{Research methods}

The method used in this study is normative approach. Juridical Normativemeans using legal norms that are explained by examining and discussing the regulations applicable law at this time, while the meaning of the word is doing empirical research in the field observation and interviews to compare the regulations actually in society.

\section{Results and Discussion}

\subsection{Duties and Responsibilities of the Running Tasks and Department Based on Act no. 2 of 2014 concerning Notary}

A notary can be held liable if it can be proved that the notary is guilty. Associated with the notary error, then used beroepsfout. Beroepsfout term is specifically devoted to the offense, the offense was committed by professionals with specialized departments, namely Doctors, Advocates and Notaries. The offenses committed in the exercise of a department. But in this case the error term objective nature within the meaning of this term in the context beroepsfout offense addressed to professionals in the exercise of his office. However, to assess the objective of understanding the offense, there are also requirements specifically to be argued, that the notary had been guilty of running his department.

The definition of the offense in general can be found in the field of criminal law. In criminal law, a person found guilty shall comply with the following elements;

- Able to take responsibility;

- Intentional or negligent;

- There is no reason forgiving;

The ability to charge a state of psychic normality and maturity or a person's intelligence leading to the ability of the three;

- Being able to understand the value and the consequences of its own;

- Being able to recognize that the act is not allowed in the view of society;

- Being able to determine the intention of committing the offense;

The first problem concerns whether the notary in the case of making authentic act correctly understand the value and consequences of the act of creation, before the end of the act declared legally flawed. In practice more found a notary who will prepare the

\footnotetext{
${ }^{6}$ Habib Adjie 2014 Hukum Notaris Indonesia Tafsir Tematik Terhadap UU No. 30 Tahun 2004 Tentang Jabatan Notaris Refika Aditama Bandung (Summized to Habib Adjie II) p. 8-10.
} 
deed tend to think of deed is valid if the parties have agreed, and each party legally competent, no object and causa allowed. This is consistent with the opinion of Koeswadji, that due to an error in the exercise of their office, notary can be caused by a lack of knowledge onvoldoende kennis, lack of experience and lack of understanding onvoldoende ervaring onvoldoende Inzicht. For example someone buys agricultural land in the name of his brother in view of the ban on ownership of agricultural land who live outside the district park land, or ban the ownership of land in excess of the maximum area. To help his client get a piece of land, on that basis then made the act by a notary is concerned, despite the fact that the land does not belong to the buyer's name listed in the deed of sale. Acquisition of land rights in the end lead to the notary less attention to the legal aspects implicit in a notarial deed, that as a notary himself obliged to produce an authentic act which serves as the perfect evidence. But in this case does not mean that the notary act can be justified, and by no means did it indicate that the notary is unable to understand the values and the consequences of the deed. In other words, a notary should understand the value and consequences of such actions. This is because a notary is not only gained theoretical knowledge, but also practical with the theoretical and technical ability, then a notary certainly have the ability, even should the notary to understand their own value and the consequences of the deed. In other words, a notary should understand the value and consequences of such actions. This is because a notary is not only gained theoretical knowledge, but also practical with the theoretical and technical ability, then a notary certainly have the ability, even should the notary to understand their own value and the consequences of the deed. In other words, a notary should understand the value and consequences of such actions. This is because a notary is not only gained theoretical knowledge, but also practical with the theoretical and technical ability, then a notary certainly have the ability, even should the notary to understand their own value and the consequences of the deed. ${ }^{7}$

In practice notary daily we will find the person (the parties) facing the public, then the act is not read by the public, but the deed was read out by the employee or assistant notary or notary not read the act before repairing, do not read the act in front of witnesses, and do not do the signing of the deed before a notary by the witnesses and the party attended. This kind of incident is often done if the notary concerned to make and receive dozens deed or deed of the day working masses, such as mortgages (mortgage) so do not have time to read and receive guests / party attended individually. ${ }^{8}$

According to Article 16 paragraph (1) letter M UUJN No. 2 of 2014, requires the notary to: "Read the act before the party attended by attended by at least two (2) witnesses, or 4 (four) special witness to the making of a will under the hand, and signed on the spot by repairing, witnesses and notary"9

\footnotetext{
${ }^{7}$ Sjaifurrachman 2011 Aspek Pertanggungjawaban Notaris dalam Pembuatan Akta Mandar Maju Bandung p. 173-175.

${ }^{8}$ Habib Adjie 2009 Meneropong Khazanah Notaris dan PPAT Indonesia (kumpulan Tulisan tentang Notaris dan PPAT) (summerized to Habib Adjie III) PT Citra Aditya Bakti Bandung p. 105.

${ }^{9}$ Law No. 2 of 2014 concerning Notary Article 16 paragraph 1 letter M.
} 
The provisions of Article 16 paragraph (1) letter M UUJN No 2 of 2014 is not mandatory under Article 16, paragraph 7, that is if: "The reading of the Act referred to in paragraph (1) letter $M$ not mandatory, if applicant requires that the act did not read because applicant have read myself, know, and understand its contents, provided that it is stated in the closing act and on every page minuta act initialed by repairing, witnesses and notary "10

In UUJN no rules or classification of the acts which may or may not include or not to include the provisions of article 16, paragraph 7 UUJN. It depends on your own judgment notary. Therefore, it is not a matter that is prohibited if at the end of the deed included provisions of Article 16, paragraph 7 UUJN at the end of all acts ${ }^{11}$

\subsection{Drawbacks of Duties and Responsibilities of the Deed made based on Act no. 2 of 2014 concerning Notary}

Achmad Sanusi put forward conditions for carrying out the lawsuit on the basis of tort are: Causalitas between an unlawful act by the loss, the proof is there adequate theory or doctrine propounded by J. von Kries, that when that loss is by customs in experience is a direct result of an unlawful act.

Further Moeljatno J. Von Kries theory defines as a condition substantially in accordance with the normal course of events that could cause results or events, which signifies normal sense:

- Depending on the subject about his views on how the so-called moral.

- Persoonlijk the defendant knew or should have know about the situation as a result.

At its core the principle of causalitas conditions that normally losses suffered by the parties is the result of a notary deed is, so it can be said that the notary act against the law. Normally, the notarial deed results in a loss, because the notary is deemed to know or should have known about the situation. A notary who prepared the legal defects normally for his actions had caused harm to his client given a notary public knows or should know, that the making of a defective law will be revoked by the court and should know the consequences of making the act. Sentence know or should know to be emphasized, arguing that a notary can not say, that he did not know the consequences of the ban, the original deed is agreed by the parties, as self-defense. A notary is required to remember a notary must know before entering the world of practice has provided practical and theoretical skills. ${ }^{12}$

The term tort (onrechtmatig DAAD) previously interpreted narrowly, that every act contrary to the rights of others arising from the law or any act which is contrary to its own legal obligations arising from the law, giving rise to an infringement. Similarly, in violation of UUJN conducted by the notary in the deed, that is not the fulfillment of the following conditions:

Violation of the provisions of Article 16 paragraph (1) L Act No. 2 of 2014 concerning Notary. Infringement by notary deed the notary did not read in front of the party attended by attended by at least two (2) witnesses and signed on the spot by

\footnotetext{
${ }^{10}$ Law No. 2 of 2014 concerning Notary Article 16 paragraph 7.

${ }^{11}$ Habib Adjie III Op. cit. p. 106

${ }^{12}$ Sjaifurrachman Op. cit. p.184-185.
} 
repairing, witnesses and a notary. Such violations include deficiencies in notary deed form, because reading in front of notary deed by the parties and the witnesses to the will of an obligation is concerned, and has done the required reading at the end of the notarial deed. that provision is expressly stated in the articles of the UUJN mentioning if hit by a notary, the notarial deed has the strength of evidence as the deed. ${ }^{13}$

In Article 1 paragraph 7 of Act no. 2 of 2014 on the amendment to Act No. 30 of 2004 concerning Notary specified three conditions is called a deed of authentic acts, which include:

- made by or in the presence of a notary

- its shape is specified in the law

- $\quad$ procedures are specified in the law ${ }^{14}$

In the code of ethics of Indonesia has set some rules that must be held by a notary (a part of UUJN), which are:

Notary personality, it is translated to:

- In performing their duties imbued Pancasila, conscious and obey the rule of notary law office, oath of office, code of ethics and good Indonesian language.

- Having professional conduct and participate in national development, especially in the field of law.

- Good personality and uphold the dignity and honor of the notary, both within and outside of their office. ${ }^{15}$

\subsection{What Solution weakness of Duties and Responsibilities}

Since the presence of institutions Notaries in Indonesia, supervision of the notary is always done by the judiciary and the government, that the purpose of the inspection to the notary when performing his respective duties to fulfill all the requirements related to the implementation of the project and Notary, in order to safeguard the public interest, because the notary appointed by the government, not for its own sake but for the sake of a notary public it serves. Another object of the supervision of the notary, that notary presented to serve the public interest that requires proof in the form of authentic documents on demand to the Notary. So in the absence of people in need of Notary, the Notary is of no use, Yet with each passing does not mean that supervisory authorities will not happen notary violations committed notary, because no matter how tight the supervisory Council of Trustees, is not easy to do the monitoring. It is up to the notary himself with full consciousness and responsibility of their office or by following the rule of law. No less important is the role of the public to monitor and continually report that the actions of his duties and not in accordance with the applicable law to the Supervisory Council of the local notary. With reports such as this can eliminate the action of which is not in accordance with the rule of law and duties of the Department.

\footnotetext{
${ }^{13}$ Habib Adjie II Op. Cit. p. 74-75.

${ }^{14}$ Salim HS 2015 Teknik Pembuatan Akta Satu PT Raja Grafindo Persada Jakarta p. 28

${ }^{15}$ Ghansham Anand 2018 Karakeristik Jabatan Notaris di Indaonesia Prenadamedia Group Jakarta p. 139
} 
Article 67 paragraph (1) UUJN Specifies that supervises the notary by the Minister. In carrying out the supervision of the Minister formed a Supervisory Council (Article 67 paragraph (2) UUJN). Article 67 paragraph (3) determine UUJN Supervisory Council consists of nine (9) members, made up of elements:

- Government of 3 (three);

- Notaries Organization of 3 (three); and

- Member / academic three (3) persons.

In Article 3, paragraph (1), Article 4 (1) and Article 5 (1) of the Regulation of the Minister determined the nomination of members of the Supervisory Council. Article 3 (1) determine the nomination of Supervisory Council Member District (MPD) with the following provisions:

- Government by the Head of Legal Services Regional Office;

- Elements of organization by the Regional Manager of the Indonesian Notaries Association;

- Elements expert / academic leaders law school or local college.

Article 4 (1) determine the nomination of members of the Supervisory Council Area (MPW) with the following provisions:

- Government by the Head of Regional Office;

- For the organization of the Regional Board Indonesian Notary Association;

- Elements expert / academic leaders law school or local college.

Article 5 (1) determine the nomination of members of the Central Supervisory Council (SRC) with the following provisions:

- Government by the Director General of General Law Administration;

- Elements of organization by the Central Board Indonesian Notary Association;

- Elements expert / academic leaders who held a university law school graduate program notaries.

According to Article 68 UUJN, that Notary Supervisory Council, comprising:

- Regional Supervisory Council;

- Territory Supervisory Council; and

- Central Supervisory Council.

Supervisory Council District (MPD) is formed and domiciled in the county or city (Article 69 paragraph (1) UUJN), Territory Supervisory Council (MPW) was formed and located in the provincial capital (Article 72 paragraph (1) UUJN), and the Central Supervisory Council ( MPP) is formed and domiciled in the country's capital (Article 76 paragraph (1) UUJN).

Supervision and inspection of the notary made by the Supervisory Council, in which there are elements of Notaries, thus at least Notary supervised and examined by members of the Supervisory Council who understand the world of the existence of members of the Supervisory Council of the notary is internal control, meaning made by fellow. While other elements of an external element representing academia, government, and society. Solidarity membership of the Supervisory Council is expected to provide synergies supervision and inspection objectives, so that each inspection is 
performed based on the rule of law, and the notary in the exercise of his duties and does not deviate from UUJN as monitored internally and externally. ${ }^{16}$

\section{Closing}

\subsection{Conclusion}

Based on the research results can be concluded as follows:

- The provisions on Duties and Responsibilities of the Law on Notary deed prepared was arranged but in practice many notaries who do not follow the rules that have been set by the Law Department of the Notary.

- Drawbacks of Duties and Responsibilities of the Legal Department of the lack of visible sanctions for violations made by the notary.

- The solution is a Notary Supervisory Council (MPN) must provide strict sanctions to notaries to refrain from further violations.

\subsection{Recommendation}

- Their rules clearer implementation especially regarding sanctions due to the setting of the responsibility must be accompanied by clear sanctions and these sanctions must be able to protect as well as safeguard public notary who made the notary deed.

- The provisions on Duties and Responsibilities of the Notary Law there should be more detailed rules for the implementation of the rules and rigor of sanctions when there are duties and responsibilities of the defaults.

- The solution of the Supervisory Council (MPN) as the agencies that oversee, check, checkers drop sanctions against the notary must provide strict sanctions and provide a deterrent effect and could be an example for other notary midges do not underestimate the responsibility of Notary.

\section{Bibliography}

[1] Ghansham Anand 2018 Karakeristik Jabatan Notaris di Indaonesia Prenadamedia Group Jakarta.

[2] Habib Adjie 2009 Meneropong Khazanah Notaris dan PPAT Indonesia (kumpulan Tulisan tentang Notaris dan PPAT PT Citra Aditya Bakti Bandung.

[3] Habib Adjie 2014 Hukum Notaris Indonesia Tafsir Tematik Terhadap UU No. 30 Tahun 2004 Tentang Jabatan Notaris Refika Aditama Bandung.

[4] Habib Adjie 2017 Sanksi Perdata dan Administratif Terhadap Notaris Sebagai Pejabat Publik Refika Aditama Bandung.

[5] Salim HS 2015 Teknik Pembuatan Akta Satu PT Raja Grafindo Persada Jakarta.

[6] Sjaifurrachman 2011 Aspek Pertanggungjawaban Notaris dalam Pembuatan Akta Mandar Maju Bandung.

\footnotetext{
${ }^{16}$ Habib Adjie I Op. Cit. p. 128-130.
} 
Volume 5 Issue 4, December 2018

[7] Act no. 2 of 2014 concerning Notary 